\title{
Inflation Thresholds and Stock Market Development: Evidence of the Nonlinear Nexus From an Emerging Economy
}

\author{
Noura Abu Asab ${ }^{1} \&$ Alaaeddin Al-Tarawneh ${ }^{1}$ \\ ${ }^{1}$ Department of Economics, School of Business, University of Jordan, Amman, Jordan \\ Correspondence: Noura Abu Asab, Department of Economics, School of Business, University of Jordan, P.O Box \\ 11942, Amman, Jordan.
}

Received: October 31, 2019

Accepted: November 30, $2019 \quad$ Online Published: December 16, 2019

doi:10.5430/ijfr.v11n1p447

URL: https://doi.org/10.5430/ijfr.v11n1p447

\begin{abstract}
The paper examines the existence of threshold effects in the relationship between inflation and stock market development in Jordan. It hypothesizes that inflation rate has positive effects on the market development before it reaches a certain level. A controlled threshold model is estimated over annul period from 1980 to 2018 . We provide evidence that the nexus between inflation and stock market development is nonlinear and the inflation threshold is detected at $1.6 \%$. The association is found positive before the threshold level but negative beyond it. However, the inflation-stock market development relationship flattens out significantly for inflation above $6 \%$. These findings are robust to alternative estimation techniques.
\end{abstract}

Keywords: financial development, inflation, threshold effect, stock market, Jordan

JEL Classification: E44, E31, O40, N25.

\section{Introduction}

The effect of inflation on macroeconomic performance has been a central topic in modern economics. In the past five decades, the relationship between inflation and macroeconomic indicators has been studied extensively. However, the early literature findings into the impact of inflation on economic and financial performance have been inconsistent and contradictory due to the linearity assumption. In fact, the recent developments in the field of econometrics and its applications have led to a renewed interest in studying whether inflation follows a nonlinear process. Therefore, a large and growing body of literature has investigated the impact of inflation on economic activity and they have shown substantial evidence on the existence of nonlinearity in the relationship between inflation and growth, which might be essentially provoked by the nonlinearity between inflation and investment-financial development. In fact, there are two strands of empirical literature: the finance-growth and inflation-growth relationship and the connected link between them is that inflation affects the economic activity through the financial sector.

Consequently, the nonlinear effects of inflation should be investigated for macroeconomic financial variables, yet, very few studies have come to detect the nonlinear nexus between inflation and stock market development and determine the threshold effects in the nexus. Among these is the study of Boyd et al (2001) which examines the relationship between inflation and four measures of stock market development for a cross-country data study and provides evidence of threshold effects over the period from 1970 to 1995 . In addition, the study of Khan et al (2006) confirms, at a large cross-country level, that the relationship between inflation and financial measures exhibits non-linearity and that the threshold level of inflation is generally found between 3-6 percent per annum. Based on an unbalanced panel data analysis, the findings revealed by Ben Naceur and Ghazouani (2005) for nine MENA countries show that marginal increase in inflation does not harm the stock market development and banking sector development.

Although cross-section and panel data studies provide high-frequent data, the time-series approach may yield accurate results that are not time-averaged or subject to selectivity bias.

This present study was spawned from the lack of research on the threshold effect of inflation on stock market development at time series levels and namely for a small open emerging market economy where the stock market can be of great importance in creating wealth for issuers, investors and stockbrokers, and in maintaining the economy 
on the route of economic growth and development (Note 1).

Hence, this paper comes to examine whether the inflation-stock market development nexus in Jordan is nonlinear and thus determine the level at which inflation turns to have a significant negative impact on stock development and if there is another threshold level after which any additional increase of inflation has no adverse influences on financial sector development. The long term implications of this study would affect the monetary policy decisions on macroeconomic stability goals. In fact, Jordan has followed a fixed exchange rate regime since October 1995, after the deterioration in the value of the currency, known as the Dinar crisis, in 1989. Despite having a price anchoring mechanism which should supposedly reduce inflation bias and inflation uncertainty, the credibility of such soft pegged exchange rate system is challenged by many economists (Asab and Cuestas, 2017) (Note 2). Indeed, over the last years, Jordan has suffered from a remarkable decline in economic activities in agriculture, mining and construction and a dangerous increase in public debt levels. Furthermore, between 2018 and 2019, the net of non-Jordanian investments in the Amman stock market showed a significant negative traded value.

Applying a controlled threshold model, we find that the inflation rate has significant negative effects on the stock market development beyond the threshold level and that the relationship exhibits nonlinearities over the years from 1980 to 2018 . The threshold level of inflation is found at $1.6 \%$, while the effect flattens at a higher inflation rate, namely after $6 \%$.

The reminder of the paper proceeds as follows: section two provides the literature review, section three illustrates the methodology; section four provides the data sources and results and section five concludes.

\section{Literature Review}

The impact of inflation on the stock market development has been controversial. Fisher (1930) hypothesises that the real rate of the economy relies on economic real factors and thereby expected inflation does not affect the real activities. If this hypothesis holds true then stocks returns can hedge for inflation (Murungi, 2012). This means that stocks are capital goods and when the general level of prices increases the stocks prices shall move in the same direction to compensate market agents for the decrease in purchasing power of money (Omran and Pointon, 2001).

On the other hand, the empirical literature has argued that inflation is negatively correlated with the stock market development (see, e.g. Bodie (1976); Nelson (1976)). One explanation to the negative nexus can be attributed to the effect of taxes on nominal capital gains (Feldstein (1980); Summers (1981); Pindyck (1984)). In addition, Modigliani and Cohn (1979) find that stocks cannot hedge for inflation since capitalization of long-run profits is affected by nominal interest rate. Furthermore, Fama (1981) states that stock prices have a negative correlation with inflation and that correlation is driven by the negative relationship between inflation and economic growth and the positive relationship between stock prices and economic activities.

There are two strands of empirical literature: the finance-growth and inflation-growth relationship and the connected link between them is that inflation affects the economic activity through the financial sector. It is argued that the rate of inflation affects at first the financial sector development through credit market frictions before it affects the economic growth (Huybens and Smith $(1998,1999)$ ). Nevertheless, a few studies have emphasised the influence of inflation thresholds in the relationship between inflation and financial market development suggesting that the negative impacts of inflation on the financial sector development becomes conspicuous once the rate of inflation reaches some threshold levels. The threshold models further point out to another threshold level (Boyd et al, 2001, Huybens and Smith 1998, 1999) at which any additional increase of rate inflation has no adverse influences on financial sector development. Accordingly, the increase in inflation affects the financial market development at some thresholds levels before the effect is passed to the economic activity.

In recent years, several studies have focused on examining the threshold effects of inflation on economic growth. Fischer (1993) has led the examination of nonlinearities in the inflation-growth nexus. Using spline regression techniques on a panel of 93 developed and developing countries, he finds that when inflation is low, its effect on economic growth is positive but turns to negative as inflation raises. Following Fisher (1993), Bruno (1995) uses a panel of 127 countries and concludes that inflation affects growth positive until a range of 15-20\% but beyond this the impact becomes negative. In addition, Sarel (1996) examines threshold effects in the inflation-growth nexus using a panel data of 87 countries by testing for structural breaks and reveals that inflation rate has a damaging effect when exceeding the 8\% level. Based on Sarel (1996)'s model, Ghosh and Phillips (1998) analyse the threshold effect of inflation on growth for a sample of 145 countries and find that the inflation threshold at 2.5\%. Similarly, Bullard and Keating (1995), Khan and Ssnhadji (2001), and David et al. (2005) among many others provide evidence of nonlinearities in the nexus between inflation and growth. 
In addition, a large body of literature has linked financial development to economic growth and provided evidence of nonlinearity nexus, e.g. Lee and Wong (2005); Adeniyi et al (2015); Law and Singh (2014); Huang and Lin (2009); Yilmazkuday (2011), yet the channel through which inflation affects the financial development has been less thoroughly explored. Indeed, a few empirical studies have come to detect the nonlinear nexus between inflation and financial market development and determine the threshold effect of the relationship. Boyd et al (2001) examine the relationship between inflation and four measures of stock market development: total stock market capitalization as a fraction of GDP, a return volatility measure, total stock value traded on GDP and the ratio of stock value traded to market capitalization (turnover) for a cross-country data of 48 countries over the yearly period from 1970 to 1995 . Data is averaged over the thirty-six year period to show steady-state relationships. Controlling the effect of real per capita GDP, secondary school enrolment, and the number of revolutions and coups, their finding of the linear regression suggests that inflation has a significantly negative impact on all financial measures except for return volatility. However, the study provides evidence of threshold effects. The authors note that after inflation exceeds a high level, i.e. $15 \%$ the increase in the level of inflation does not have any further negative impact on stock market development measures, i.e. the inflation-stock market development relationship flattens significantly for high values of inflation. But the authors find that return volatility is best represented by a positive linear relationship with inflation.

Furthermore, using a large cross-country sample of 168 developed and developing countries over the period 1960-1999, the empirical unbalanced panel analysis by Khan et al (2006) confirms the nonlinearity of the relationship between inflation and financial measures. The threshold level of inflation is generally found between 3-6 percent per annum. The study of Tsaurai (2017) explores the maximum inflation threshold levels beyond which financial development declines in the South-Eastern Asian markets during 1994-2014. The findings reveal that lower rates of inflation are good for financial development whilst higher levels of inflation hamper the development. Ehigiamusoe et al. (2019) examines the moderating effect of inflation on the finance-growth nexus for the West African countries during 1980-2014 and the inflation threshold level is found at 5.62 percent. Additionally, Kim et al (2010) Study the long- and short-run relationship between inflation and financial development and provide evidence, using the Pooled Mean Group estimator for unbalanced panel data of 87 countries, that inflation affects financial development positively in the short-run relationship, and this relationship only holds in low-income or low-inflation economies.

At a time series level, the study of Falahati et al (2012) investigates the relationship between inflation and stock market development in Iran during the period from 1999 to 2008. The threshold model, estimated by the conditional least square method, suggests no threshold for inflation effects on stock market.

This present study focuses upon examining the relationship between inflation and stock market development for the case of Jordan which may exhibit nonlinearity and it is spawned from the lack of research on the threshold effect of inflation on stock market development at time series levels.

\section{Methodology}

The paper utilises the methodology of Khan and Senhadji (2001) which is developed by Chan and Tsay (1998) and Hansen (1999) in panel data models with threshold effects. The threshold model for a specific country is given as:

$$
\begin{gathered}
M C Y_{t}=\delta_{0}+\delta_{1}\left(1-d_{t}^{\pi^{*}}\right)\left\{\left(\pi_{t}-1\right) I\left(\pi_{t} \leq 1\right)+\log \left(\pi_{t}\right) I\left(\pi_{t}>1\right)\right\}+\delta_{-} 2 d_{-} t^{\wedge}\left(\pi^{\wedge} *\right)\left\{\left(\pi_{-} t-1\right) I\left(\pi_{-} t \leq 1\right)\right. \\
\left.+\log \left(\pi_{-} t\right) I\left(\pi_{-} t>1\right)\right\}+\beta X_{-} t+\varepsilon_{-} t \\
\mathrm{~d}_{\mathrm{t}}^{\pi^{*}}=\left\{\begin{array}{l}
1 \text { if } \pi_{\mathrm{t}}>\pi^{*} \\
0 \text { if } \pi_{\mathrm{t}} \leq \pi^{*}
\end{array}\right.
\end{gathered}
$$

Where $\mathrm{MCY}_{\mathrm{t}}$ is Stock Market Capitalization as a share of GDP at time t, considered as a proxy for the stock market development, $\delta_{0}$ is the constant, $\delta_{1}$ is the coefficient of the semi-log transformation of inflation at time $t, \delta_{2}$ is the coefficient of extra inflation. $\pi_{t}$ is the inflation rate at time t. $d_{t}^{\pi^{*}}$ is a dummy variable that takes the value of 1 when the realized inflation rate exceeds the threshold level of inflation, set ascendingly from 1 to $\bar{\pi}$ with increment of 0.1 percent, and zero when inflation rate is below or equal that threshold level. The parameter $\pi^{*}$ denotes the threshold inflation level, $\mathrm{X}_{\mathrm{t}}$ contains the most important and relevant variables found in the literature of the stock market development (Note 3), this includes: stock market liquidity (Traded Value) to GDP (VY), broad money to GDP (MY) 
- as a measure of financial intermediary development-, the ratio of investment to GDP (IY) (Note 4). Therefore, equation (1) can be extended as follows.

$$
\begin{aligned}
M C Y_{t} & =\delta_{0}+\delta_{1}\left(1-d_{t}^{\pi^{*}}\right)\left\{\left(\pi_{t}-1\right) I\left(\pi_{t} \leq 1\right)+\log \left(\pi_{t}\right) I\left(\pi_{t}>1\right)\right\}+\delta_{-} 3 d_{-} t^{\wedge}\left(\pi^{\wedge} *\right)\left\{\left(\pi_{-} t-1\right) I\left(\pi_{-} t \leq 1\right)\right. \\
& \left.+\log \left(\pi_{-} t\right) I\left(\pi_{-} t>1\right)\right\}+\beta_{-} 1 V Y_{-} t+\beta_{-} 2 I Y_{-} t+\beta_{-} 3 M Y_{-} t+\varepsilon_{-} t
\end{aligned}
$$

However, since the threshold level of inflation is unknown; the model cannot be estimated by the ordinary least square. Instead the Non Linear Least Square (NLLS) should be used. Nevertheless, as the optimal threshold level of inflation is nonlinear and non-differentiable, the NLLS's classical gradient search techniques are incorrect. Therefore, the estimation of the threshold model should be performed by the method of conditional least squares.

The threshold inflation level takes the following property: (i) $\delta_{1}$ representing low inflation; (ii) $\delta_{2}$ representing extra inflation; (iii) $\delta_{1}+\delta_{2}$ representing high inflation. This indicates that when $\delta_{2}$ is significant, then both $\left(\delta_{1}+\delta_{2}\right)$ should be added to see the impact on the market development. By estimating regressions for the range of $\pi$ to $\bar{\pi}$, chosen in an ascending order with increment of 0.1 , the threshold value of $\pi$ is selected by detecting the value that minimizes the sum of squared residuals, that is:

$$
\pi^{*}=\operatorname{argmin}_{\pi}[S(\pi), \pi=\underline{\pi, \ldots, \bar{\pi}}]
$$

Where $\left(\mathrm{S}\left(\pi^{*}\right)\right)$ is the sum square of residuals which is minimized with the fixed threshold level of inflation at $\pi^{*}$.

Khan and Senhadji (2001) use the log transformation of inflation which is preferred to the level of inflation because it eliminates asymmetry in the inflation distribution (Sarel, 1996) and provides the best fit of model (Ghosh and Phillips, 1998) since it smoothes the time trend in the data. This provides continuity in the relationship that prevents small changes around the threshold level from resulting in different effects when inflation is increasing or decreasing (Khan and Senhadji, 2001). To avoid missing values on negative inflation rates or negative infinity values for rates close to zero, the applied strategy specifies a hybrid function of inflation that is logarithmic for inflation rates above one and linear for inflation rates below or equal one. The function is represented as:

$$
f\left(\pi_{t}\right)=\left(\pi_{t}-1\right) I\left(\pi_{t} \leq 1\right)+\log \left(\pi_{t}\right) I\left(\pi_{t}>1\right)
$$

The first term of the inflation function refers to the level of inflation multiplied by an indicator function, $I$, which ignores all inflation rates above unity. Note that one is subtracted from the first term to allow the function to be continuous at unity. The second term is the log of inflation multiplied by the indicator function that includes all the inflation observation above one. The function is continuously differentiable, i.e. it considers all the positive and negative inflation observations (Khan and Senhadji, 2001). This continuity of the function ensures the symmetry of the inflation rate.

In terms of the confidence interval, Chan and Tsay (1998) proves that the asymptotic distribution of all parameters in the threshold model including the threshold level have a normal distribution. They show that the NLLS estimate of $\phi=\left\{\delta_{0} \delta_{1} \delta_{2} \beta, \pi^{*}\right\}$ follows an asymptotic normal distribution:

$$
\hat{\phi} \sim \mathrm{N}\left(\phi, \epsilon^{-1} \mathrm{~V} \epsilon^{-1}\right)
$$

Where $\epsilon=E\left(H_{t} \grave{H}_{t}\right), V=E\left(\varepsilon_{t}^{2} H_{t} \grave{H}_{t}\right), H_{t}=\left(-\widetilde{X}_{t}, \delta_{1}\left(1-d_{t}^{\pi^{*}}\right)+\delta_{2} d_{t}^{\pi^{*}}\right), \widetilde{X_{t}}$ is the vector of all control variables in equation (3). The estimation of $\epsilon$ and $\mathrm{V}$ where $\mathrm{T}$ is the number of observation can be illustrated as follows:

$$
\begin{gathered}
\hat{\epsilon}=\frac{\sum_{t=1}^{T} \widehat{H}_{t} \widehat{\hat{H}}_{t}}{T} \\
\widehat{V}=\frac{\sum_{t=1}^{T} \hat{\varepsilon}_{t}^{2} \widehat{H}_{t} \widehat{H}_{t}}{T}
\end{gathered}
$$

With

$$
\widehat{H_{t}}=\left(-\bar{X}_{t}, \delta_{1}\left(1-d_{t}^{\pi^{*}}\right)+\delta_{2} d_{t}^{\pi^{*}}\right)
$$

To examine the nonlinearity constraint or the existence of threshold effects i.e. the two regime model, the hypothesis $H_{0}: \delta_{1}=\delta_{2}$ is tested. However, because the parameter of inflation threshold is unidentified the classical tests, such as the t-test, have non-standard distribution. Hansen $(1996,1999)$ sets forth a bootstrap method to induce the asymptotic distribution of the following likelihood ratio: 


$$
L R_{0}=\frac{S_{0}-S_{1}}{\hat{\sigma}^{2}}
$$

Where $S_{0}$ and $S_{1}$ refer to the square sum of residuals under linearity $\left(H_{0}: \delta_{1}=\delta_{2}\right)$ and nonlinearities $\left(H_{1}: \delta_{1} \neq \delta_{2}\right)$, respectively, and $\hat{\sigma}^{2}$ is the variance of the residuals under $\mathrm{H}_{1}$. The statistics of the LR are not normally distributed, so Hansen computed their non-rejection region $\mathrm{c}(\alpha)$ and $\alpha$ is a given asymptotic level.

If, $L R_{0} \leq c(\alpha)$, where $c(\alpha)=-2 \ln (1-\sqrt{1-\alpha)}$, the null hypothesis of linearity cannot be rejected (Khan and Senhadji, 2001) (Lee and Wong, 2005) .

\section{Data Sources and Results}

\subsection{Data and Descriptive Statistics}

Data on the ratio of stock market capitalization and stock market liquidity to GDP are extracted from Amman stock market database. Inflation rate and the ratio of investment as a fraction of GDP are imported from the World Bank Development Indicators database, while the ratio of broad money to GDP is taken from the Central Bank of Jordan's statistical database. All data cover the yearly span from 1980 to 2018. According to the descriptive statistics reported in Table 1, the average inflation rate of the study span is roughly $5 \%$ with a maximum value of $25 \%$ in 1989 , the year in which the exchange rate had remarkable depreciations. Table 1 provides descriptive statistics of all the variables.

The dynamic properties of financial and macroeconomic time series have received great concern over the last fifty years, especially for long term data. The test of Dickey and Fuller was widely used to test for stationarity. Nevertheless, the test has been criticized for ignoring structural breaks which according to Perron (1990) may lead to a bias that reduces the ability to reject the unit root hypothesis. Perron $(1988,1990)$ suggests for instance that the observations of 1973 oil crisis should be treated as points of structural changes and thus the unit root hypothesis can be rejected in favour of a trend stationary hypothesis. However, the break locations can rarely be anticipated a priori. Therefore, it is preferred to apply endogenous break unit root tests. Zivot-Andrews (2003) develop a data dependent algorithm to detect a structural break in the data allowing for unconditional unit root test. The test has three models: Model (A) with a shift in intercept; Model (B) with a shift in slope and Model (C) with a shift in intercept and slope.

Nonetheless, the debate on the dynamic properties has been intensified with the introduction of the minimum LM test by Lee and Strazicich $(2003,2004)$ which allows for two structural breaks in the data. The test suggests three models: The crash model (A) for one time change in intercept; model (B) for change in trend slope; and model (C) for change in both level and trend.

We apply model "C" for both tests to examine the stationary of the respected series. Both tests provide evidence against the unit root hypothesis for all the series in favour of the alternative, i.e. trend stationarity process. The results are reported in Table 2 Panel (A) and (B).

Table 1. Descriptive statistics

\begin{tabular}{lllll}
\hline Variable & Mean & Median & Maximum & Minimum \\
\hline $\mathrm{MCY}_{\mathrm{t}}$ & 0.869 & 0.704 & 2.987 & 0.398 \\
\hline$\pi_{\mathrm{t}}$ & 4.752 & 3.516 & 25.712 & -0.876 \\
\hline $\mathrm{VY}_{\mathrm{t}}$ & 0.258 & 0.097 & 1.890 & 0.031 \\
\hline $\mathrm{IY}_{\mathrm{t}}$ & 0.251 & 0.247 & 0.438 & 0.166 \\
\hline $\mathrm{MY}_{\mathrm{t}}$ & 3.118 & 1.675 & 8.860 & 0.182 \\
\hline
\end{tabular}

Table 2. Unit root tests

\begin{tabular}{lllll}
\hline & \multicolumn{2}{l}{ Panel (A) Zivot-Andrews } & \multicolumn{2}{l}{ Panel (B) Lee-Strazicich* } \\
\hline Variable & Test Statistic & Break & Test Statistic & Break \\
\hline $\mathrm{MCY}_{\mathrm{t}}$ & $-6.451^{* * *}$ & 2004 & $-9.456^{* * *}$ & 2003,2011 \\
\hline$\pi_{\mathrm{t}}$ & $-4.569^{* *}$ & 1991 (Note 5) & $-6.210^{* *}$ & 1998,2007 \\
\hline
\end{tabular}




\begin{tabular}{lllll}
\hline $\mathrm{VY}_{\mathrm{t}}$ & $-6.377 * * *$ & 2005 & $-11.031 * * *$ & 2003,2014 \\
\hline $\mathrm{IY}_{\mathrm{t}}$ & $-4.689 * *$ & 1992 & $-6.838 * *$ & 1991,2003 \\
\hline $\mathrm{MY}_{\mathrm{t}}$ & $-7.434 * * *$ & 2005 (Note 6) & $-11.604 * * *$ & 2003,2008 \\
\hline
\end{tabular}

Note: *Critical values for Model $\mathrm{C}=-6.932,-6.175,-5.825$ at $1 \%, 5 \%, 10 \%$, respectively. Break refers to the data break, determined by the test. The null hypothesis is that the series is non stationary with structural break(s) and the alternative denotes stationarity with break(s).

\subsection{Empirical Results}

This section presents the empirical results of the linear and nonlinear regressions of the inflation-stock market development nexus. The linear regression of the relationship is found negative at $10 \%$ level of significance as can be seen from Table 3. In addition, all the control variables appear significant at 5 percent level and have positive effects on the aggregate market development.

To investigate the threshold levels in the nexus, the threshold level is estimated by the conditional least square method. The optimal threshold level of inflation $\pi^{*}$ is determined by finding the value that minimizes the sum square of residuals (RSS).

The threshold level is detected at $1.6 \%$, as shown in Figure 1, after which the nexus turns to a significant negative one. Before this threshold level, inflation has significant positive effects on the stock market development. The estimation of the threshold model is provided in Table 4.

In addition, the results suggest that when inflation is above the threshold of $1.6 \%$ and below the rate of $6 \%$, the effect of inflation on the stock market development is negative, i.e. when $\pi=1 \%$ the relationship is positive while it is negative at $1.8 \%$. The effect of extra inflation dominates after the threshold level and after $3.8 \%$ the positive impact of low inflation fades away. However, the relationship flattens after the inflation rate of $6 \%$ so that the effect of extra inflation has no further negative impacts on the market development. That is, beyond the threshold level the aggregate traded value ratio declines continuously but once it reaches $6 \%$ the relationship disappear. At all inflation rate levels, the control variables that proxy market liquidity, investment and financial intermediary development have a robust positive and significant relationship with the market value as suggested by theory and empirical literature.

To examine the existence of threshold effects the hypothesis $\mathrm{H}_{0}: \delta_{1}=\delta_{2}$ is tested and the observed value of the likelihood ratio, is given in Table 5 Panel B. The distribution of the significance levels is bootstrapped. The null hypothesis of no threshold effects is highly rejected at $1 \%$ level of significance, as LR0>C $(\alpha)$, providing evidence of threshold effects.

The specification of the threshold model at the threshold level of $1.6 \%$ is statistically meaningful and it lacks of autocorrelation and heterskedasticity problems. The specification tests results are reported in Table 5 Panel A.

To check the robustness of the controlled threshold results by the conditional least square, the threshold model was re-estimated using the Two Stage Least square procedure (2SLS). The first stage of 2SLS involves running OLS estimation for each variable on a set of instruments; the model instruments are:

$$
\operatorname{MCY}_{\mathrm{t}}(-1)\left(1-\mathrm{d}^{\pi^{*}}\right) \mathrm{f}\left(\pi_{\mathrm{t}}\right) \mathrm{d}^{\pi^{*}} \mathrm{f}\left(\pi_{\mathrm{t}}\right) \operatorname{vy}(-1) \text { iy }(-1) \operatorname{my}(-1) \operatorname{rgdpp}(-1)
$$

The set of instruments includes the first lags of the explanatory variables and the stock market development indicator. In the second stage the original equation is estimated but with the fitted values obtained from the first stage regression (Note 7). The results of the regression are presented in Table 6.

The results are found highly robust to the change in estimation technique. The findings by 2SLS method confirm that the threshold level of inflation is $1.6 \%$ as presented in Table 6 . In order to save space, the results by conditional least square and 2SLS are reported for specific $\pi^{*}$; the full estimation can be obtained from author upon request. 
Table 3. Linear regression

\begin{tabular}{ll}
\hline Variable & Coefficient \\
\hline C & $\begin{array}{l}0.290^{* *} \\
(0.148)\end{array}$ \\
\hline inflation & $\begin{array}{l}-0.011^{*} \\
(0.006)\end{array}$ \\
\hline VY & $1.077^{* * *}$ \\
& $(0.101)$ \\
\hline \multirow{2}{*}{ IY } & $0.936^{*}$ \\
& $(0.535)$ \\
\hline \multirow{2}{*}{ MY } & $0.038^{* *}$ \\
& $(0.014)$ \\
\hline R-Square & 0.909 \\
\hline F-Statistic & 85.086 \\
\hline Prob. & 0.000 \\
\hline
\end{tabular}

Note: $* * *, * * *$ denote significance at $1 \%, 5 \%$ and $10 \%$, respectively.Standard Errors are between parentheses.

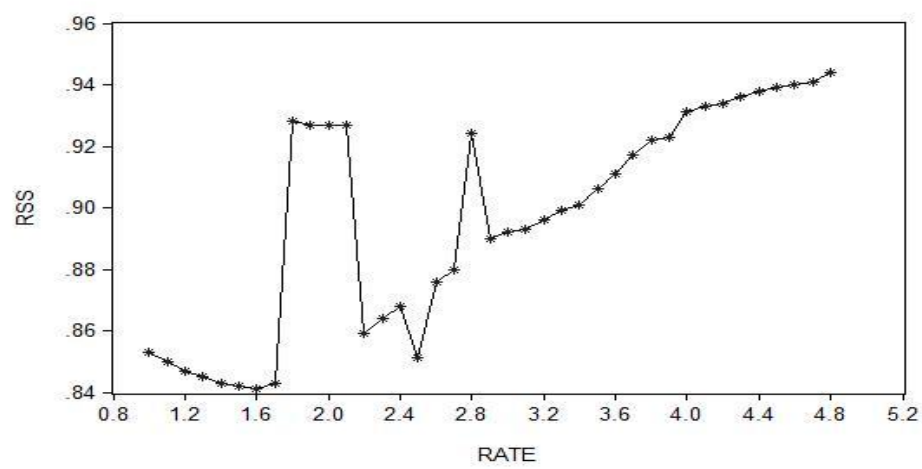

Figure 1. Inflation rate and RSS

Note: The minimization of the RSS is at the inflation rate of $1.6 \%$.

Table 4. Estimation of threshold model by conditional least square

\begin{tabular}{lllll}
\hline & Coefficient & Coefficient & Coefficient & Coefficient \\
\hline$\delta_{0}$ & $\pi^{*}=1.0$ & $\pi^{*}=1.10$ & $\pi^{*}=1.20$ & $\pi^{*}=1.30$ \\
\hline$\delta_{1}$ & $0.374 * * *$ & $0.366^{* * *}$ & $0.358^{* * * *}$ & $0.351^{* * *}$ \\
& $(0.086)$ & $(0.086)$ & $(0.086)$ & $(0.086)$ \\
\hline$\delta_{2}$ & $0.199^{* * *}$ & $0.193^{* * *}$ & $0.186^{* * *}$ & $0.180^{* * *}$ \\
& $(0.043)$ & $(0.047)$ & $(0.045)$ & $(0.044)$ \\
\hline$\beta_{1}$ & $-0.142^{* * *}$ & $-0.145^{* * *}$ & $-0.147^{* * *}$ & $-0.149^{* * *}$ \\
\hline
\end{tabular}




\begin{tabular}{|c|c|c|c|c|}
\hline & $(0.092)$ & (0.091) & $(0.091)$ & $(0.090)$ \\
\hline & Coefficient & Coefficient & Coefficient & Coefficient \\
\hline \multirow[t]{2}{*}{$\beta_{2}$} & $1.175 * * *$ & $1.173 * * *$ & $1.170 * * *$ & $1.167 * * *$ \\
\hline & $(0.375)$ & $(0.376)$ & $(0.376)$ & $(0.376)$ \\
\hline \multirow[t]{2}{*}{$\beta_{3}$} & $0.049 * * *$ & $0.049 * * *$ & $0.049 * * *$ & $0.048 * * *$ \\
\hline & $(0.012)$ & $(0.012)$ & $(0.012)$ & $(0.012)$ \\
\hline RSS & 0.853 & 0.850 & 0.847 & 0.845 \\
\hline \multirow[t]{2}{*}{ R-squared } & 0.927 & 0.927 & 0.928 & 0.928 \\
\hline & $\pi^{*}=1.4$ & $\pi^{*}=1.5$ & $\pi^{*}=1.6$ & $\pi^{*}=1.7$ \\
\hline \multirow[t]{2}{*}{$\delta_{0}$} & $0.343 * * *$ & $0.337 * * *$ & $0.330 * * *$ & $0.326 * * *$ \\
\hline & $(0.086)$ & $(0.086)$ & $(0.086)$ & $(0.084)$ \\
\hline \multirow[t]{2}{*}{$\delta_{1}$} & $0.174 * * *$ & $0.168 * * *$ & $0.162 * * *$ & $0.157 * * *$ \\
\hline & $(0.086)$ & $(0.041)$ & $(0.039)$ & $(0.038)$ \\
\hline \multirow[t]{2}{*}{$\delta_{2}$} & $-0.151 * * *$ & $-0.152 * * *$ & $-0.154 * * *$ & $-0.155^{* * *}$ \\
\hline & $(0.053)$ & $(0.054)$ & $(0.054)$ & $(0.055)$ \\
\hline \multirow{2}{*}{$\beta_{1}$} & $1.037 * * *$ & $1.038 * * *$ & $1.039 * * *$ & $1.041 * * *$ \\
\hline & $(0.089)$ & $(0.089)$ & (0.089) & $(0.088)$ \\
\hline \multirow[t]{2}{*}{$\beta_{2}$} & $1.164 * * *$ & $1.160 * * *$ & $1.156 * * *$ & $1.148 * * *$ \\
\hline & $(0.376)$ & $(0.375)$ & $(0.375)$ & $(0.374)$ \\
\hline \multirow[t]{2}{*}{$\beta_{3}$} & $0.048 * * *$ & $0.048 * * *$ & $0.047 * * *$ & $0.047 * * *$ \\
\hline & $(0.012)$ & $(0.012)$ & $(0.012)$ & $(0.012)$ \\
\hline RSS & 0.843 & 0.842 & 0.841 & 0.843 \\
\hline \multirow[t]{2}{*}{ R-squared } & 0.928 & 0.928 & 0.929 & 0.928 \\
\hline & $\pi^{*}=1.8$ & $\pi *=1.9$ & $\pi^{*}=2.0$ & $\pi *=2.1$ \\
\hline \multirow[t]{2}{*}{$\delta_{0}$} & $0.323 * * *$ & $0.325 * * *$ & $0.328 * * *$ & 0.330 \\
\hline & $(0.088)$ & $(0.088)$ & $(0.088)$ & $(0.089)$ \\
\hline \multirow[t]{2}{*}{$\delta_{1}$} & $0.152 * * *$ & $0.148 * * *$ & $0.144 * * *$ & $0.140 * * *$ \\
\hline & $(0.038)$ & $(0.038)$ & $(0.038)$ & $(0.038)$ \\
\hline \multirow[t]{2}{*}{$\delta_{2}$} & $-0.157 * * *$ & $-0.159 * * *$ & $-0.162 * *$ & $-0.164 * *$ \\
\hline & $(0.056)$ & $(0.058)$ & $(0.060)$ & $(0.061)$ \\
\hline \multirow[t]{2}{*}{$\beta_{1}$} & $1.0142 * * *$ & $1.045 * * *$ & $1.048 * * *$ & $1.051 * * *$ \\
\hline & $(0.088)$ & $(0.087)$ & $(0.087)$ & $(0.087)$ \\
\hline \multirow[t]{2}{*}{$\beta_{2}$} & $1.136^{* * *}$ & $1.114 * * *$ & $1.091 * * *$ & $1.068 * * *$ \\
\hline & $(0.372)$ & $(0.368)$ & $(0.364)$ & $(0.360)$ \\
\hline \multirow[t]{2}{*}{$\beta_{3}$} & $0.047 * * *$ & $0.046^{* * *}$ & $0.045 * * *$ & $0.045 * * *$ \\
\hline & $(0.012)$ & $(0.012)$ & $(0.012)$ & $(0.012)$ \\
\hline RSS & 0.846 & 0.849 & 0.852 & 0.855 \\
\hline \multirow[t]{2}{*}{ R-squared } & 0.928 & 0.927 & 0.927 & 0.927 \\
\hline & $\pi^{*}=2.2$ & $\pi^{*}=2.3$ & $\pi^{*}=2.4$ & $\pi^{*}=2.5$ \\
\hline$\delta_{0}$ & $0.332 * * *$ & $0.333 * * *$ & $0.334 * * *$ & 0.315 \\
\hline
\end{tabular}




\begin{tabular}{|c|c|c|c|c|}
\hline & $(0.089)$ & $(0.090)$ & $(0.091)$ & $(0.088)$ \\
\hline \multirow[t]{2}{*}{$\delta_{1}$} & $0.136 * * *$ & $0.131 * * *$ & $0.126 * * *$ & 0.127 \\
\hline & $(0.035)$ & $(0.038)$ & $(0.038)$ & $(0.034)$ \\
\hline \multirow[t]{2}{*}{$\delta_{2}$} & $-0.166 * *$ & $-0.168 * *$ & $-0.169 * *$ & $-0.167 * *$ \\
\hline & $(0.062)$ & $(0.063)$ & $(0.065)$ & $(0.064)$ \\
\hline \multirow[t]{2}{*}{$\beta_{1}$} & $1.054 * * *$ & $1.056 * * *$ & $1.059 * * *$ & $1.053 * * *$ \\
\hline & $(0.086)$ & $(0.086)$ & $(0.086)$ & $(0.083)$ \\
\hline \multirow[t]{2}{*}{$\beta_{2}$} & $1.046 * * *$ & $1.026 * * *$ & $1.001 * * *$ & $1.042 * * *$ \\
\hline & $(0.357)$ & $(0.350)$ & $(0.351)$ & $(0.351)$ \\
\hline \multirow[t]{2}{*}{$\beta_{3}$} & $0.044 * * *$ & $0.043 * * *$ & $0.043 * * *$ & $0.044 * * *$ \\
\hline & $(0.012)$ & $(0.012)$ & $(0.012)$ & $(0.012)$ \\
\hline RSS & 0.859 & 0.864 & 0.868 & 0.851 \\
\hline \multirow[t]{2}{*}{ R-squared } & 0.927 & 0.926 & 0.926 & 0.927 \\
\hline & $\pi^{*}=2.6$ & $\pi^{*}=2.7$ & $\pi^{*}=2.8$ & $\pi^{*}=2.9$ \\
\hline \multirow[t]{2}{*}{$\delta_{0}$} & $0.333 * * *$ & 0.332 & $0.331 * * *$ & $0.330 * * *$ \\
\hline & $(0.093)$ & $(0.094)$ & $(0.094)$ & $(0.095)$ \\
\hline \multirow[t]{2}{*}{$\delta_{1}$} & $0.117 * * *$ & $0.112 * * *$ & $0.107 * * *$ & $0.102 * *$ \\
\hline & $(0.038)$ & $(0.038)$ & $(0.038)$ & $(0.038)$ \\
\hline \multirow[t]{2}{*}{$\delta_{2}$} & $-0.173 * *$ & $-0.174 * *$ & $-0.175 * *$ & $-0.176 * *$ \\
\hline & $(0.067)$ & $(0.068)$ & $(0.069)$ & $(0.070)$ \\
\hline \multirow[t]{2}{*}{$\beta_{1}$} & $1.063 * * *$ & $1.065 * * *$ & $1.067 * * *$ & $1.068 * * *$ \\
\hline & $(0.085)$ & $(0.085)$ & $(0.085)$ & $(0.084)$ \\
\hline \multirow[t]{2}{*}{$\beta_{2}$} & $0.985 * * *$ & $0.974 * * *$ & $0.964 * * *$ & $0.954 * * *$ \\
\hline & $(0.348)$ & $(0.008)$ & $(0.346)$ & $(0.345)$ \\
\hline \multirow[t]{2}{*}{$\beta_{3}$} & $0.042 * * *$ & $0.041 * * *$ & $0.040 * * *$ & $0.040 * * *$ \\
\hline & $(0.012)$ & $(0.012)$ & $(0.012)$ & $(0.012)$ \\
\hline RSS & 0.876 & 0.880 & 0.924 & 0.890 \\
\hline \multirow[t]{2}{*}{ R-squared } & 0.925 & 0.925 & 0.885 & 0.924 \\
\hline & $\pi^{*}=3.0$ & $\pi^{*}=3.1$ & $\pi^{*}=3.2$ & $\pi^{*}=3.3$ \\
\hline \multirow[t]{2}{*}{$\delta_{0}$} & $0.329 * * *$ & $0.331 * * *$ & $0.334 * * *$ & 0.336 \\
\hline & $(0.096)$ & $(0.096)$ & $(0.097)$ & $(0.097)$ \\
\hline \multirow[t]{2}{*}{$\delta_{1}$} & $0.098 * *$ & $0.095 * *$ & $0.092 * *$ & $0.088 * *$ \\
\hline & $(0.038)$ & $(0.038)$ & $(0.039)$ & $(0.039)$ \\
\hline \multirow[t]{2}{*}{$\delta_{2}$} & $-0.178 * *$ & $-0.180 * *$ & $-0.182 * *$ & $-0.184 * *$ \\
\hline & $(0.071)$ & $(0.073)$ & $(0.074)$ & $(0.076)$ \\
\hline \multirow[t]{2}{*}{$\beta_{1}$} & $1.069 * * *$ & $1.070 * * *$ & $1.071 * * *$ & $1.072 * * *$ \\
\hline & $(0.084)$ & $(0.084)$ & $(0.083)$ & $(0.083)$ \\
\hline \multirow[t]{2}{*}{$\beta_{2}$} & $0.943 * * *$ & $0.927 * * *$ & $0.909 * * *$ & $0.892 * * *$ \\
\hline & $(0.344)$ & $(0.342)$ & $(0.340)$ & $(0.338)$ \\
\hline$\beta_{3}$ & $0.040 * * *$ & $0.039 * * *$ & $0.039 * * *$ & $0.038 * * *$ \\
\hline
\end{tabular}




\begin{tabular}{|c|c|c|c|c|}
\hline & $(0.012)$ & $(0.012)$ & $(0.012)$ & $(0.012)$ \\
\hline RSS & 0.892 & 0.893 & 0.896 & 0.899 \\
\hline \multirow[t]{2}{*}{ R-squared } & 0.924 & 0.924 & 0.923 & 0.923 \\
\hline & $\pi^{*}=3.4$ & $\pi^{*}=3.5$ & $\pi^{*}=3.6$ & $\pi^{*}=3.7$ \\
\hline \multirow[t]{2}{*}{$\delta_{0}$} & $0.339 * * *$ & $0.341 * * *$ & $0.342 * * *$ & $0.342 * * *$ \\
\hline & $(0.098)$ & $(0.098)$ & $(0.097)$ & $(0.097)$ \\
\hline \multirow[t]{2}{*}{$\delta_{1}$} & $0.086^{* *}$ & $0.083^{* *} *$ & $0.079 *$ & $0.076^{*}$ \\
\hline & $(0.039)$ & $(0.039)$ & $(0.040)$ & $(0.040)$ \\
\hline \multirow[t]{2}{*}{$\delta_{2}$} & $-0.187 * *$ & $-0.189 * *$ & $-0.192 * *$ & $-0.195 * *$ \\
\hline & $(0.078)$ & $(0.079)$ & $(0.082)$ & $(0.084)$ \\
\hline \multirow{2}{*}{$\beta_{1}$} & $1.073 * * *$ & $1.074 * * *$ & $1.077 * * *$ & 1.079 \\
\hline & $(0.083)$ & $(0.082)$ & $(0.082)$ & $(0.082)$ \\
\hline \multirow[t]{2}{*}{$\beta_{2}$} & $0.878 * *$ & $0.865 * *$ & $0.857 * *$ & $0.850 * *$ \\
\hline & $(0.336)$ & $(0.333)$ & $(0.331)$ & $(0.330)$ \\
\hline \multirow[t]{2}{*}{$\beta_{3}$} & $0.038 * * *$ & $0.037 * * *$ & $0.037 * * *$ & $0.036 * * *$ \\
\hline & $(0.012)$ & $(0.012)$ & $(0.012)$ & $(0.012)$ \\
\hline RSS & 0.901 & 0.906 & 0.911 & 0.917 \\
\hline \multirow{2}{*}{ R-squared } & 0.923 & 0.923 & 0.922 & 0.922 \\
\hline & $\pi^{*}=3.8$ & $\pi^{*}=3.9$ & $\pi^{*}=4.0$ & $\pi^{*}=4.1$ \\
\hline \multirow[t]{2}{*}{$\delta_{0}$} & $0.342 * * *$ & $0.342 * * *$ & $0.342 * * *$ & $0.343^{*} * *$ \\
\hline & $(0.097)$ & $(0.097)$ & $(0.097)$ & $(0.097)$ \\
\hline \multirow[t]{2}{*}{$\delta_{1}$} & $0.072 *$ & 0.068 & 0.065 & 0.062 \\
\hline & $(0.040)$ & $(0.040)$ & $(0.041)$ & $(0.041)$ \\
\hline \multirow[t]{2}{*}{$\delta_{2}$} & $-0.197 * *$ & $-0.199 * *$ & $-0.202 * *$ & $-0.206^{* *}$ \\
\hline & $(0.086)$ & $(0.088)$ & $(0.091)$ & $(0.093)$ \\
\hline \multirow[t]{2}{*}{$\beta_{1}$} & $1.082 * * *$ & $1.080 * * *$ & $1.087 * * *$ & $1.090 * * *$ \\
\hline & $(0.082)$ & $(0.082)$ & $(0.082)$ & $(0.082)$ \\
\hline \multirow[t]{2}{*}{$\beta_{2}$} & $0.844 * *$ & $0.838 * *$ & $0.833 * *$ & $0.827 * *$ \\
\hline & $(0.328)$ & $(0.327)$ & $(0.326)$ & $(0.326)$ \\
\hline \multirow[t]{2}{*}{$\beta_{3}$} & $0.036 * * *$ & $0.036 * * *$ & $0.035 * * *$ & $0.034 * * *$ \\
\hline & $(0.012)$ & $(0.012)$ & $(0.012)$ & $(0.012)$ \\
\hline RSS & 0.922 & 0.923 & 0.931 & 0.933 \\
\hline \multirow[t]{2}{*}{ R-squared } & 0.921 & 0.921 & 0.920 & 0.920 \\
\hline & $\pi^{*}=4.2$ & $\pi^{*}=5.9$ & $\pi^{*}=6.0$ & $\pi^{*}=6.1$ \\
\hline \multirow[t]{2}{*}{$\delta_{0}$} & $0.343 * * *$ & $0.339 * * *$ & $0.308 * * *$ & $0.304 * * *$ \\
\hline & $(0.098)$ & $(0.098)$ & $(0.106)$ & $(0.107)$ \\
\hline \multirow[t]{2}{*}{$\delta_{1}$} & 0.060 & 0.039 & 0.008 & 0.004 \\
\hline & $(0.041)$ & $(0.041)$ & $(0.049)$ & $(0.050)$ \\
\hline \multirow[t]{2}{*}{$\delta_{2}$} & $-0.210 * *$ & $-0.232 *$ & $-0.236^{*}$ & -0.235 \\
\hline & $(0.096)$ & $(0.096)$ & $(0.138)$ & $(0.139)$ \\
\hline
\end{tabular}




\begin{tabular}{lllll}
\hline$\beta_{1}$ & $1.092^{* * *}$ & $1.098^{* * *}$ & $1.098^{* * *}$ & $1.089^{* * *}$ \\
& $(0.082)$ & $(0.086)$ & $(0.092)$ & $(0.093)$ \\
\hline$\beta_{2}$ & $0.823^{* *}$ & $0.794^{* *}$ & $0.808^{* *}$ & $0.812^{* *}$ \\
& $(0.327)$ & $(0.325)$ & $(0.338)$ & $(0.339)$ \\
\hline$\beta_{3}$ & $0.034^{* * *}$ & $0.033^{* * *}$ & $0.035^{* * *}$ & $0.035^{* * *}$ \\
& $(0.012)$ & $(0.012)$ & $(0.012)$ & $(0.012)$ \\
\hline RSS & 0.934 & 0.955 & 0.998 & 1.002 \\
\hline R-squared & 0.920 & 0.919 & 0.915 & 0.915 \\
\hline
\end{tabular}

Note: $* * *, * *, *$ denote significance at $1 \%, 5 \%$ and $10 \%$, respectively. Robust standard Errors are between parentheses. Results are reported for specific $\pi^{*}$; the full estimation can be obtained from authors upon request.

Table 5. Coefficient and residuals diagnostics at threshold level $\pi^{*}=1.60 \%$

\begin{tabular}{llll}
\hline $\begin{array}{l}\text { Panel (A): } \\
\text { Breusch-Godfrey LM }\end{array}{ }^{(1)}$ & \multicolumn{2}{l}{ Diagnostic Tests } \\
Harvey \\
F-statistic & 0.588 & F-statistic & 1.80 \\
\hline Prob. $(2,31)$ & 0.561 & Prob. $(2,31)$ & 0.15 \\
\hline Panel (B): & $\underline{\text { Threshold }^{(2)}}$ & & \\
& $\underline{\text { Effects Test }^{(3)}}$ & & \\
\hline Threshold Estimate (\%) & $\underline{\text { LR }}$ & Critical Value & Significance Level \\
\hline 1.6 & $\underline{9.160}$ & 8.390 & 0.001 \\
\hline
\end{tabular}

Note: ${ }^{(1)}$ The null hypothesis of no autocorrelation at lag order '2'. (2) The null hypothesis states homoskedasticity. ${ }^{(3)}$ LR is the observed value of the likelihood ratio, where the critical value and the significance level are bootstrapped. The readers are referred to Hansen (1999) for more details on the bootstrap distribution of the likelihood ratio.

Table 6. Estimation of threshold Model by the 2SLS

\begin{tabular}{lllll}
\hline & Coefficient & Coefficient & Coefficient & Coefficient \\
\hline$\delta_{0}$ & $\pi^{*}=1.0$ & $\pi^{*}=1.10$ & $\pi^{*}=1.20$ & $\pi^{*}=1.30$ \\
\hline$\delta_{1}$ & $0.499^{* * *}$ & $0.493^{* * *}$ & $0.487^{* * *}$ & $0.481^{* * *}$ \\
& $(0.150)$ & $(0.149)$ & $(0.148)$ & $(0.147)$ \\
\hline$\delta_{2}$ & $0.177^{* * *}$ & $0.172^{* * *}$ & $0.166^{* * *}$ & $0.161^{* * *}$ \\
& $(0.045)$ & $(0.044)$ & $(0.043)$ & $(0.042)$ \\
\hline$\beta_{1}$ & $-0.130^{* * *}$ & $-0.133^{* * *}$ & $-0.133^{* * *}$ & $-0.138^{* * *}$ \\
& $(0.040)$ & $(0.041)$ & $(0.041)$ & $(0.041)$ \\
\hline$\beta_{2}$ & $1.124^{* * *}$ & $1.126^{* * *}$ & $1.128^{* * *}$ & $1.130^{* * *}$ \\
& $(0.140)$ & $(0.139)$ & $(0.139)$ & $(0.138)$ \\
\hline$\beta_{3}$ & 0.781 & 0.778 & 0.774 & 0.769 \\
& $(0.122)$ & $(0.491)$ & $(0.490)$ & $(0.489)$ \\
\hline RSS & $0.028^{* *}$ & $0.027^{* *}$ & $0.027^{* *}$ & $0.027 * *$ \\
\hline & $(0.031)$ & $(0.012)$ & $(0.012)$ & $(0.012)$ \\
\hline
\end{tabular}




\begin{tabular}{|c|c|c|c|c|}
\hline R-squared & 0.920 & 0.921 & 0.921 & 0.921 \\
\hline & $\pi^{*}=1.4$ & $\pi^{*}=1.5$ & $\pi^{*}=1.6$ & $\pi^{*}=1.7$ \\
\hline \multirow[t]{2}{*}{$\delta_{0}$} & $0.475 * * *$ & $0.469 * * *$ & $0.464 * * *$ & $0.462 * * *$ \\
\hline & $(0.147)$ & $(0.146)$ & $(0.146)$ & $(0.147)$ \\
\hline \multirow[t]{2}{*}{$\delta_{1}$} & $0.156 * * *$ & $0.151 * * *$ & $0.146 * * *$ & $0.141 * * *$ \\
\hline & $(0.041)$ & $(0.040)$ & $(0.040)$ & $(0.040)$ \\
\hline \multirow[t]{2}{*}{$\delta_{2}$} & $-0.141 * * *$ & $-0.143 * * *$ & $-0.144 * * *$ & $-0.146 * * *$ \\
\hline & (0.044) & $(0.045)$ & $(0.045)$ & $(0.046)$ \\
\hline \multirow[t]{2}{*}{$\beta_{1}$} & $1.132 * * *$ & $1.134 * * *$ & $1.136 * * *$ & $1.139 * * *$ \\
\hline & (0.138) & $(0.138)$ & $(0.137)$ & $(0.137)$ \\
\hline \multirow[t]{2}{*}{$\beta_{2}$} & 0.764 & 0.759 & 0.754 & 0.739 \\
\hline & $(0.488)$ & $(0.487)$ & $(0.486)$ & $(0.486)$ \\
\hline \multirow[t]{2}{*}{$\beta_{3}$} & $0.026^{* * *}$ & $0.026^{* *}$ & 0.026 & 0.026 \\
\hline & $(0.012)$ & $(0.012)$ & $(0.012)$ & $(0.012)$ \\
\hline RSS & 0.907 & 0.906 & 0.905 & 0.908 \\
\hline \multirow[t]{2}{*}{ R-squared } & 0.921 & 0.921 & 0.922 & 0.921 \\
\hline & $\pi^{*}=5.9$ & $\pi *=6$ & $\pi^{*}=6.1$ & $\pi^{*}=6.2$ \\
\hline \multirow[t]{2}{*}{$\delta_{0}$} & $0.536 * *$ & $0.531 * *$ & $0.526^{* *}$ & $0.520 * *$ \\
\hline & (0.209) & $(0.209)$ & (0.209) & $(0.209)$ \\
\hline \multirow[t]{2}{*}{$\delta_{1}$} & 0.020 & 0.016 & 0.012 & 0.007 \\
\hline & $(0.049)$ & $(0.048)$ & $(0.048)$ & $(0.048)$ \\
\hline \multirow[t]{2}{*}{$\delta_{2}$} & $-0.274 *$ & $-0.273 *$ & $-0.272 *$ & -0.271 \\
\hline & $(0.143)$ & $(0.148)$ & $(0.148)$ & $(0.151)$ \\
\hline \multirow[t]{2}{*}{$\beta_{1}$} & $1.232 * * *$ & $1.232 * * *$ & $1.232 * * *$ & 1.232 \\
\hline & $(0.152)$ & $(0.152)$ & $(0.153)$ & $(0.153)$ \\
\hline \multirow[t]{2}{*}{$\beta_{2}$} & 0.156 & 0.162 & 0.168 & 0.176 \\
\hline & $(0.621)$ & $(0.621)$ & $(0.621)$ & $(0.620)$ \\
\hline \multirow[t]{2}{*}{$\beta_{3}$} & 0.007 & 0.007 & 0.007 & 0.007 \\
\hline & $(0.015)$ & $(0.015)$ & $(0.015)$ & $(0.015)$ \\
\hline RSS & 1.107 & 1.110 & 1.116 & 1.120 \\
\hline R-squared & 0.904 & 0.904 & 0.903 & 0.903 \\
\hline
\end{tabular}

Note: Results are reported for specific $\pi^{*}$; the full estimation can be obtained from authors upon request. Instrument Specification: $\mathrm{MCY}_{\mathrm{t}}(-1)\left(1-\mathrm{d}^{\pi^{*}}\right) \mathrm{f}\left(\pi_{\mathrm{t}}\right) \mathrm{d}^{\pi^{*}} \mathrm{f}\left(\pi_{\mathrm{t}}\right) \operatorname{VY}(-1) \operatorname{IY}(-1) \mathrm{MY}(-1) \quad . \quad * * *, \quad * *, \quad * \quad$ denote significance at $1 \%, 5 \%$ and $10 \%$, respectively. Robust standard Errors are between parentheses.

\section{Concluding Remarks and Policy Implications}

The paper comes to examine the nonlinear relationship between inflation and the aggregate financial market development in Jordan over the yearly span from 1980 to 2018. The threshold model of Khan and Senhadji (2001) is applied and estimated by conditional least square and two stage least square methods. Control variables that represent market liquidity, investment and financial intermediary development are incorporated and threshold level of inflation is detected at $1.6 \%$. When inflation rate exceeds this threshold, the negative influence of inflation on the market development persists. However, the nexus flattens out beyond the inflation rate of $6 \%$ so inflation has no 
further negative impacts on the stock market development.

These findings would be of particular relevance to various stakeholders such as policy makers, regulators, investors and researchers. The paper helps having a better understanding of the relationship between inflation and stock market development which assists framing the macroeconomic policies relating to inflation and its impact on stock market development. Nonetheless, the paper recommends considering the sensitivity of data frequency that may affect the location and magnitude of the threshold level once quarterly data becomes available for Jordan. In addition, further empirical investigations are needed to estimate the effect of inflation on market development for other countries and on other aspects of stock market, such as market liquidity and activity.

\section{References}

Adeniyi, O., Oyinlola, A., Omisakin, O., \& Egwaikhide, F. O. (2015). Financial development and economic growth in Nigeria: Evidence from threshold modelling. Economic Analysis and Policy, 47, 11-21. https://doi.org/10.1016/j.eap.2015.06.003

Akinnifesi, E. (1984). Inflation in Nigeria: Causes, consequences and control. CBNBullion, 1, 61-75.

Alexander, W. R. J. (1997). Inflation and economic growth: evidence from a growth equation. Applied Economics, 29(2), 233-238. https://doi.org/10.1080/000368497327290

Al-Tarawneh, A., \& Al-Assaf, G. (2018). Macroeconomic Drivers of Stock Market Development: Evidence from Jordan. International Journal of Financial Research, 9(3), 117-124. https://doi.org/10.5430/ijfr.v9n3p117

Asab, N. A., \& Cuestas, J. C. (2017). The Credibility of a Soft Pegged Exchange Rate in Emerging Market Economies: Evidence from a Panel Data Study. Annals of Economics \& Finance, 18(1), 29-51.

Ben Naceur, S., Ghazouani, S., \& Omran, M. (2007). The determinants of stock market development in the Middle-Eastern and North African region. Managerial Finance, 33(7), 477-489.

Bodie, Z. (1976). Common stocks as a hedge against inflation. The Journal of Finance, 31(2), 459-470. https://doi.org/10.1111/j.1540-6261.1976.tb01899.x

Boudoukh, J., Richardson, M., \& Whitelaw, R. F. (1994). Industry returns and the Fisher effect. The Journal of Finance, 49(5), 1595-1615. https://doi.org/10.1111/j.1540-6261.1994.tb04774.x

Boyd, J. H., Levine, R., \& Smith, B. D. (2001). The impact of inflation on financial sector performance. Journal of Monetary Economics, 47(2), 221-248. https://doi.org/10.1016/S0304-3932(01)00049-6

Bruno, M. (1995). Does inflation really lower growth?. Finance and Development, 32(3), 35.

Bullard, J., \& Keating, J. W. (1995). The long-run relationship between inflation and output in postwar economies. Journal of Monetary Economics, 36(3), 477-496. https://doi.org/10.1016/0304-3932(95)01227-3

Chan, K. S., \& Tsay, R. S. (1998). Limiting properties of the least squares estimator of a continuous threshold autoregressive model. Biometrika, 85(2), 413-426. https://doi.org/10.1093/biomet/85.2.413

Cizkowicz, P., \& Rzonca, A. (2013). Does inflation harm corporate investment? Empirical evidence from OECD countries. Economics, 7(16), 1-41. https://doi.org/10.5018/economics-ejournal.ja.2013-16

David, D., Pedro, G.-P., \& Paula, H. (2005). Threshold effects in the relationship between inflation and growth: A new panel-data approach. Munich Personal RePEc Archive 38225 (pp. 1-19).

Ehigiamusoe, K. U., Lean, H. H., \& Lee, C. C. (2019). Moderating effect of inflation on the finance-growth nexus: insights from West African countries. Empirical Economics, 57(2), 399-422. https://doi.org/10.1007/s00181-018-1442-7

Falahati, A., Nouri, F., \& Rostami, A. (2012). The effect of inflation on development of stock market. Journal of Basic and Applied Scientific Research, 2(11), 11460-11468.

Fama, E. F. (1981). Stock returns, real activity, inflation, and money. The American Economic Review, 71(4), 545-565.

Feldstein, M. S. (1980). Inflation, tax rules, and investment: Some econometric evidence. National Bureau of Economic Research, Working Paper No. 577. https://doi.org/10.3386/w0577

Fischer, S. (1993). The role of macroeconomic factors in growth. Journal of Monetary Economics, 32(3), 485-512. https://doi.org/10.1016/0304-3932(93)90027-D

Fisher, I. (1930). The Theory of Interest. New York. https://doi.org/10.1086/260579 
Friedman, M. (1977). Nobel lecture: inflation and unemployment. Journal of Political Economy, 85(3), 451-472.

Garcia, V. F., \& Liu, L. (1999). Macroeconomic determinants of stock market development. Journal of Applied Economics, 2(1), 29-59. https://doi.org/10.1080/15140326.1999.12040532

Ghosh, A., \& Phillips, S. (1998). Warning: Inflation may be harmful to your growth. IMF Staff Papers, 45(4), 672-710. https://doi.org/10.2307/3867589

Hansen, B. (1996, March). Inference When a Nuisance Parameter Is Not Identified Under the Null Hypothesis. Econometrica, 64, 413-30. https://doi.org/10.2307/2171789

Hansen, B. E. (1999). Threshold effects in non-dynamic panels: Estimation, testing, and inference. Journal of Econometrics, 93(2), 345-368. https://doi.org/10.1016/S0304-4076(99)00025-1

Hartman, R. (1972). The effects of price and cost uncertainty on investment. Journal of Economic Theory, 5(2), 258-266. https://doi.org/10.1016/0022-0531(72)90105-6

Ho, S. Y., \& Odhiambo, N. M. (2018). Analysing the Macroeconomic Drivers of Stock Market Development in the Philippines. Cogent Economics and Finance, 6, 1451265. https://doi.org/10.1080/23322039.2018.1451265

Ho, S., \& Njindan Iyke, B. (2017). Determinants of Stock Market Development: a review of the literature. Studies of Economics and Finance, 32(1), 143-164. https://doi.org/10.1108/SEF-05-2016-0111

Huang, H. C., \& Lin, S. C. (2009). Non-linear finance-growth nexus: A threshold with instrumental variable approach 1. Economics of Transition, 17(3), 439-466. https://doi.org/10.1111/j.1468-0351.2009.00360.x

Huybens, E., \& Smith, B. (1999). Inflation, financial markets, and long-run real activity. Journal of Monetary Economics, 43, 283-315. https://doi.org/10.1016/S0304-3932(98)00060-9

Huybens, E., \& Smith, B. D. (1998). Financial market frictions, monetary policy, and capital accumulation in a small open economy. Journal of Economic Theory, 81(2), 353-400. https://doi.org/10.1006/jeth.1997.2372

Johnson, H. G. (1967). Is inflation a retarding factor in economic growth. Fiscal and Monetary Problems in Developing States (pp. 121-137).

Khan, M. S., \& Ssnhadji, A. S. (2001). Threshold effects in the relationship between inflation and growth. IMF Staff papers, 48(1), 1-21.

Khan, M. S., Senhadji, A. S., \& Smith, B. D. (2006). Inflation and financial development. Macroeconomic Dynamics, 10, 165-182. https://doi.org/10.1017/S1365100506050152

Kim, D. H., \& Lin, S. C. (2010). Dynamic relationship between inflation and financial development. Macroeconomic Dynamics, 14(3), 343-364. https://doi.org/10.1017/S1365100509090312

Law, S. H., \& Singh, N. (2014). Does too much finance harm economic growth?. Journal of Banking and Finance, 41, 36-44. https://doi.org/10.1016/j.jbankfin.2013.12.020

Lee, C., \& Wong, S. (2005). Inflationary threshold effects in the relationship between financial development and economic growth: evidence from Taiwan and Japan. Journal of Economic Development, 30(1), 49.

Lee, J., \& Strazicich, M. C. (2003). Minimum Lagrange multiplier unit root test with two structural breaks. Review of Economics and Statistics, 85(4), 1082-1089. https://doi.org/10.1162/003465303772815961

Lee, J., \& Strazicich, M. C. (2004). Minimum LM unit root test with one structural break. Manuscript (pp. 1-16), Department of Economics, Appalachian State University.

Modigliani, F., \& Cohn, R. A. (1979). Inflation, rational valuation and the market. Financial Analysts Journal, 24-44. https://doi.org/10.2469/faj.v35.n2.24

Murungi, C. (2012). The Impact of Inflation on Stock Market Returns and Volatility: Evidence From Nairobi Securities Exchange. Unpublished MBA report.

Nell, K. S. (2000). Is low inflation and precondition for faster growth? the case of South Africa. Technical report, Department of Economics Discussion Paper, University of Kent.

Nelson, C. R. (1976). Inflation and rates of return on common stocks. The Journal of Finance, 31(2), 471-483.

Omran, M., \& Pointon, J. (2001). Does the inflation rate affect the performance of the stock market? The case of Egypt. Emerging Markets Review, 2(3), 263-279. https://doi.org/10.1016/S1566-0141(01)00020-6

Perron, P. (1988). Trends and random walks in macroeconomic time series: Further evidence from a new approach. 
Journal of Economic Dynamics and Control, 12(2-3), 297-332. https://doi.org/10.1016/0165-1889(88)90043-7

Perron, P. (1990). Testing for a unit root in a time series with a changing mean. Journal of Business \& Economic Statistics, 8(2), 153-162. https://doi.org/10.1080/07350015.1990.10509786

Pindyck, R. S. (1983). Risk, inflation, and the stock market. Working Paper No. 824, National Bureau of Economic Research. https://doi.org/10.3386/w1186

Sarel, M. (1996). Nonlinear effects of inflation on economic growth. IMF Staff Papers, 43(1), $199-215$. https://doi.org/10.2307/3867357

Sidrauski, M. (1967). Inflation and economic growth. The Journal of Political Economy, 796-810. https://doi.org/10.1086/259360

Stockman, A. C. (1981). Anticipated inflation and the capital stock in a cash in-advance economy. Journal of Monetary Economics, 8(3), 387-393. https://doi.org/10.1016/0304-3932(81)90018-0

Summers, L. H. (1981). Inflation and the valuation of corporate equities. Working Paper No. 824, National Bureau of Economic Research. https://doi.org/10.3386/w0824

Thirlwall, A. P., \& Barton, C. A. (1971). Inflation and growth: the international evidence. PSL Quarterly Review, 24(98), 1-7.

Tobin, J. (1965). Money and economic growth. Econometrica: Journal of the Econometric Society, 671-684.

Tsaurai, K. (2017). Inflation Thresholds-Financial Development Nexus in South-Eastern Asian Emerging Markets. Journal of Economics and Behavioral Studies, 9(4), 14-24. https://doi.org/10.22610/jebs.v9i4.1818

Tsaurai, K. (2018). What are the determinants of stock market development in emerging markets?. Academy of Accounting and Financial Studies Journal, 22(2), 1-11.

Wai, U. T. (1959). The relation between inflation and economic development: a statistical inductive study. IMF Staff Papers, 7(2), 302-317. https://doi.org/10.2307/3866244

Yilmazkuday, H. (2011). Thresholds in the finance-growth nexus: A cross-country analysis. The World Bank Economic Review, 25(2), 278-295. https://doi.org/10.1093/wber/lhr011

Zivot, E., \& Andrews, D. W. K. (2002). Further evidence on the great crash, the oil-price shock, and the unit-root hypothesis. Journal of Business and Economic Statistics, 20(1), 25-44.

\section{Notes}

Note 1. In fact, the non-Jordanian investors' ownership in companies listed at the Amman Stock Exchange represented $50.5 \%$ of the total market value.

Note 2. According to the IMF's 2017 report on Jordan, the central bank tries to maintain the fixed exchange rate system by increasing the level of interest rate differential with the base country.

Note 3. Literature on the macroeconomic determinants of stock market development, namely market capitalization, provides evidence that the most important determinants are financial intermediary development, stock market liquidity and stabilization factors. (Naceur et al, 2007); (Garcia and Liu, 1999); (Ho and Njindan, 2017); (Ho and Odhiambo, 2018); (Tsaurai, 2018).

Note 4. Al-Tarawneh and Al-Assaf (2018) find that the Traded Value to GDP, broad money to GDP, the ratio of investment to GDP and the real per capita GDP (RGDP) are the key factors determining the development of the Amman stock market. They found that these variables have a positive significant effect on the stock market in Jordan. In our study, the RGDP is dropped from the model as it is found insignificant in all threshold models.

Note 5. This might be due to the consequences of the 1990 Gulf War.

Note 6. The structural break in 2003-2005 could be attributed to the 2003 Iraqi's War and the change in foreign interest rates passed by the fixed exchange rate regime.

Note 7. The exogenous variables in the model are specified as both regressors and instruments. 